\title{
Moderation Effect Of Counter Work Productive Behaviour On The Relationship Between Job Satisfaction And Organizational Citizenship Behaviour
}

\author{
${ }^{1}$ Dr. Gayathri Band, ${ }^{2}$ Dr. Rajesh Timane, ${ }^{3}$ Prof. Priyanka Wandhe \\ ${ }^{1}$ Shri Ramdeobaba College of Engineering and Management, Nagpur, India \\ ${ }^{2}$ PDIMTR, Nagpur, India \\ ${ }^{3}$ PDIMTR, Nagpur, India
}

Article History: Received:11 January 2021; Accepted: 27 February 2021; Published online: 5 April 2021

\begin{abstract}
OCB ordinarily alludes to practices that decidedly affect the association or its individuals (Poncheri, 2006). OCB can be influenced by imparting in workers an impression of skill in their activity undertakings (Todd, 2003). Bateman and Organ (1983) proposed a noteworthy and solid connection between organizational citizenship conduct and job satisfaction. Bateman and Organ (1983) proposed a critical and strong association between organizational citizenship and occupation fulfillment. Employment fulfillment has been found to have a positive association with work execution and organizational citizenship. The purpose of the present examination was to research if CWB could be gone with moderately high work fulfillment. The present study is undertaken to study if there is a significant moderating effect of CWB on the relationship between Job Satisfaction and Organizational Citizenship Behaviour. CWB is prejudicious to the organization or to co-workers. The Organizations ought to enhance the spontaneous organizational citizenship behaviors of workers to extend satisfaction and, hence, to extend the competitiveness within the organization. The survey results disclosed that job satisfaction encompasses an important positive impact on organizational citizenship behaviour which counterwork productive behaviour encompasses a important negative dampening impact on the link between job satisfaction and organizational citizenship behaviours. The organizations will improve the work satisfaction of their workers by rising perceived operating satisfaction, social satisfaction, and remunerative satisfaction, which might then improve the organizational citizenship behaviours and reduce the negative impact of counterwork productive behaviour.
\end{abstract}

KEYWORDS: Organizational Citizenship Behaviour (OCB), Job Satisfaction (JS), Counterproductive Work Behaviour (CWB), Moderation

\section{INTRODUCTION: ORGANIZATIONAL CITIZENSHIP BEHAVIOUR (OCB)}

OCB can be portrayed as securing the affiliation when it is rebuked or requesting that friends place assets into this affiliation (Turnipseed and Rassuli, 2005), or a conduct that outperforms routine wants (Daniels et al. 2006). OCB ordinarily alludes to practices that decidedly affect the association or its individuals (Poncheri, 2006). OCB can be influenced by imparting in workers an impression of skill in their activity undertakings (Todd, 2003). There is convincing proof that OCB is a result reliable with a social trade relationship (Cirka et al. 1999). OCBs yield essentially higher results in the long haul than in the here and now for the association (Daniels et al. 2006). Fast changes in the social and social structures of the affiliations and society have provoke a significant impact on the conduct of delegates at work place.

\section{JOB SATISFACTION (JS)}

Smith, Organ and Near (1983), Batman and Organ (1983) directed the main inquiry on precursors of organizational citizenship conduct. They found that activity fulfillment is the best indicator of organizational citizenship conduct. Bateman and Organ (1983) and Smith, Organ, and Near (1983) demonstrated out that the degree JS addresses a positive personality state, satisfied agents participate in citizenship. Bateman and Organ (1983) proposed an imperative and strong association between OCB and JS.

\section{COUNTERPRODUCTIVE WORK BEHAVIOUR (CWB)}

Employees likewise harbor the potential for conduct that is wrong and unsafe to the firm and their collaborators. The causes and kinds of such conduct have for quite some time been a subject of enthusiasm for hierarchical brain research. The point of the present examination was to investigate if CWB could be gone with moderately high work satisfaction. Minor organizational offences incorporate broadening breaks, leaving early, deliberately working gradually, wasting supplies and tattling about the association with outcasts.

RELATIONSHIP BETWEEN JOB SATISFACTION AND ORGANIZATIONAL CITIZENSHIP BEHAVIOR 
Organ (1977) recommended that the absence of experimental help for such a relationship comes from the meaning of execution. Organ (1988) proposed that activity fulfillment and OCB were connected in a strong bond. Following Organ's proposal, the principal state of mind whose association with OCB examined was work fulfillment (Moorman, Niehoff, and Organ, 1993).

As per Organ (1990), the premise of the connection between work fulfillment and OCB is social trade hypothesis which expresses that when certain conditions are available individuals respond the individuals who advantage them. Attributable to the method of reasoning that Organ (1977, 1988a) proposed for the connection amongst JS and OCB the "fulfillment causes execution" (Farh, Podsakoff, and Organ, 1990).

\section{COUNTERPRODUCTIVE WOR BEHAVIOUR AS MODERTOR}

CWB is concept to be participated in as a skill to minimize negative feelings brought on by way of environmental stressors. Negative feelings elicit humans to pick out an tournament as incongruent with their private goals. Therefore, people can also have issue thinking about their work and performing at excellent levels, which in turn, lead to negative affect (emotion) and CWB.

The present study is undertaken to study if there is a significant moderating effect on the relationship between Job Satisfaction and Organizational Citizenship Behaviour.

\section{MATERIALS \& METHODS:}

\section{The Current Study}

The purpose of this study was to identify the effect of Counterproductive Work Behavior on the relationship between Job Satisfaction and Organizational Citizenship Behaviour. Specifically, we hypothesized the following:

Hypothesis 1: Job satisfaction has a positive association with OCB.

Hypothesis 2: CWB moderates the relationship between JS and OCB

\section{Participants}

Participants were 400 employees at a variety of organizations across India. The employees were mostly middle level employees and working in the same organization for atleast 3 years. Of these, $320(80 \%)$ were lower and middle level employees, and $80(20 \%)$ were top level employees. The employees were from various sectors of industry \& services in India. The questionnaire was circulated by google forms. The total complete forms received and used for analysis was 363. Of the 363 participants, 145 (37\%) were men and $218(63 \%)$ were women.

\section{Measures}

Job Satisfaction: The job satisfaction stage of each participant was once measured through using Short Form Minnesota Satisfaction Questionnaire (MSQ) developed through Weiss, Davis, England, and Lofquist (1967) and again translated to Turkish by way of Tuncel (2000). It measures both intrinsic and extrinsic job satisfaction.

The questionnaire consists of 20 items and respondents had to rate each of them on a 5-point Likert type scale according to their level of satisfaction with the related item.

Organizational Citizenship Behavior: The OCB scale designed by Podsakoff and associates (1990) in view of Organ's (1988) five dimensional scientific classification has been used for analysis. The back interpretation strategy was utilized to guarantee that the scale was deciphered legitimately by Ünüvar (2006). OCB has 24 statements and respondents were asked to rate the things on a five-point scale. The scale was $1=$ "Very Inaccurate", 3= "Uncertain", 5= "Very Accurate".

Counterproductive work behavior: Counterproductive work behaviors was measured with a behavioral guidelines based totally on a master list compiled from a variety of current measures. 24 statements from Bennett and Robinson(2002) was used for research. 
The reliabilities of the three scales are as given below in Table 1 . The Cornbach alpha coefficients were as 0.81 for Job Satisfaction, 0.89 Counterproductive Work Behaviors (CWB) and 0.83 for Organizational Citizenship Behaviors.

Table 1: Cronbach Alpha for the Scales

\begin{tabular}{|l|c|c|}
\hline \multicolumn{1}{|c|}{ Scale Name } & Number of Items & $\boldsymbol{\alpha}$ \\
\hline Job Satisfaction & 20 & 0.81 \\
\hline Organizational Citizenship Behavior & 24 & 0.83 \\
\hline Counterproductive Work Behaviors & 11 & 0.89 \\
\hline
\end{tabular}

Figure 1: Model

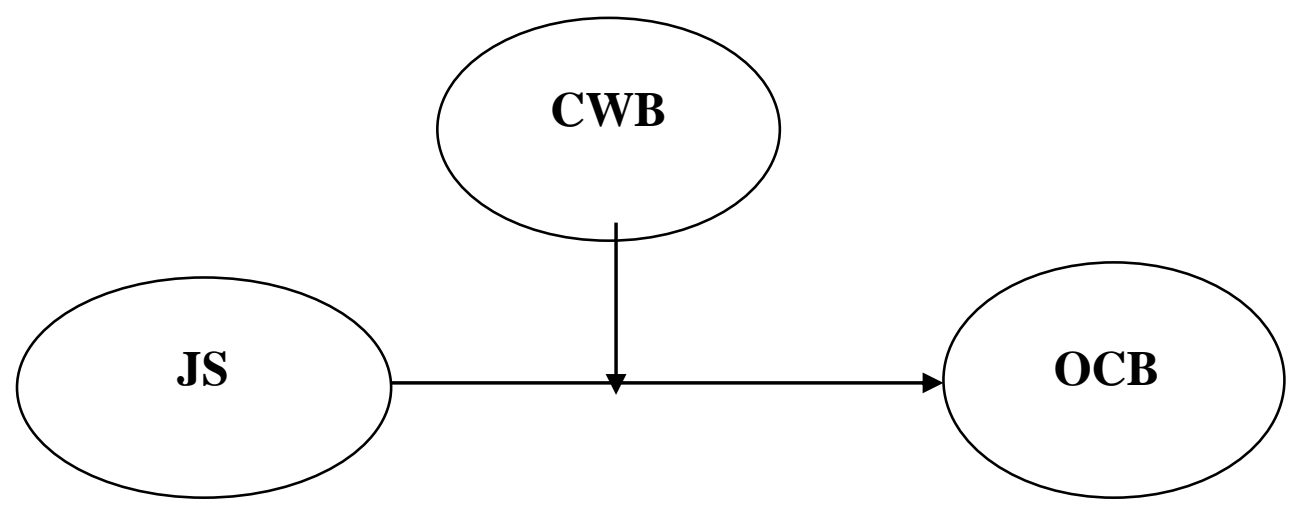

\section{RESULTS AND DISCUSSION:}

Model : 1

$\mathrm{Y}: \mathrm{OCB}$

$\mathrm{X}: \mathrm{JS}$

$\mathrm{W}: \mathrm{CWB}$

Sample

Size: 363

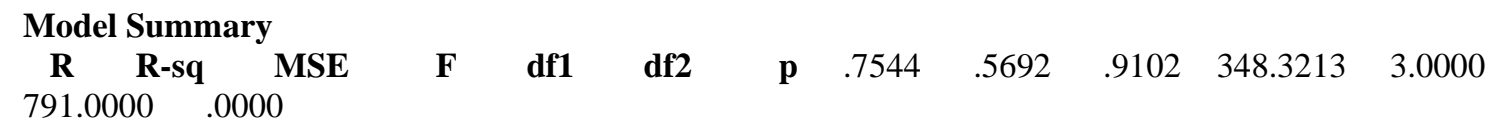

$\mathrm{R}$ is the correlation between the found values of $\mathrm{Y}$ and the values of $\mathrm{Y}$ estimated by the regression model. Therefore, giant values of the R symbolize a giant correlation between the predicted and observed values of the consequence which is 0.7544 in the above result.

As such, $\mathrm{R}$ is a gauge of how nicely the model predicts the determined data. It follows that the resulting $\mathrm{R}^{2}$ can be interpreted as the amount of version in the effect variable that is accounted for by way of the predictors in the model. We can say $56.92 \%$ of variation in Organizational Citizenship Behaviour is accounted for through the variables used in the model

Model

$$
\begin{array}{llllll}
\text { coeff } & \text { se } & \mathbf{t} & \mathbf{p} & \text { LLCI } & \text { ULCI }
\end{array}
$$

$\begin{array}{lllllll}\text { constant } & -2.6558 & .6050 & -4.3900 & .0000 & -3.8433 & -1.4682\end{array}$

$\begin{array}{lllllll}\text { JS } & .8117 & .1160 & 6.9993 & .0000 & .5840 & 1.0393\end{array}$

$\begin{array}{llllllll}\text { CWB } & .7867 & .0854 & 9.2161 & .0000 & .6191 & .9542\end{array}$

$\begin{array}{lllllll}\text { Int_1 } & -.0549 & .0148 & -3.7000 & .0002 & -.0840 & -.0258\end{array}$

Product terms key:

Int_1 : IQ $\quad x \quad$ CI 
The first section of the table gives us estimates for these b-values and these values indicate the man or woman contribution of each predictor to the model. The b-values inform us about the relationship between Job Satisfaction and every predictor. If the cost is superb we can tell that there is a fine relationship between the predictor and the outcome, whereas a bad coefficient represents a terrible relationship. The b-values tell us greater than this, though. They tell us to what degree each predictor affects the result if the results of all other predictors are held constant.

The t-statistic can be derived that tests whether a b-value is substantially exclusive from 0 It is best to conceptualize the t-tests as measures of whether the predictor is making a considerable contribution to the model. Therefore, if the t-test related with a b-value is great (if the price in the column labelled Sig. is less than $.05)$ then the predictor is making a sizeable contribution to the model. The smaller the value of Sig. and the large the value of $t$, the increased the contribution of that predictor. Hence looking at the $t$ value we can say that Job Satisfaction has a positive relationship with Organizational Citizenship Behaviour. The b value of the combined interplay of Job Satisfaction and Counterwork Productive Behaviour is negative and is sizeable as p-value is much less than 0.05 consequently CWB is having a sizable dampening (negative) moderating impact on the relationship between Job Satisfaction and OCB.

\section{Conditional effects of the focal predictor at values of the moderator(s):}

\begin{tabular}{cccccccc} 
CI & Effect & se & $\mathbf{t}$ & $\mathbf{p}$ & \multicolumn{2}{c}{ LLCI } & \multicolumn{2}{c}{ ULCI } \\
6.5000 & .4549 & .0406 & 11.2073 & .0000 & .3752 & .5346 \\
8.0000 & .3726 & .0396 & 9.4185 & .0000 & .2949 & .4502 \\
9.5000 & .2903 & .0497 & 5.8376 & .0000 & .1927 & .3879
\end{tabular}

$\mathrm{W}$ values in conditional tables are the 16th, 50th, and 84th percentiles.

The interaction was probed by testing the conditional effects of Counterwork Productive Behaviour at three levels of low medium and high levels. The mean value is the medium level. At all the three levels the $p$ value is significant showing that CWB has a significant moderating effect on the relationship between JS and OCB at all levels of CWB.

\section{CONCLUSION:}

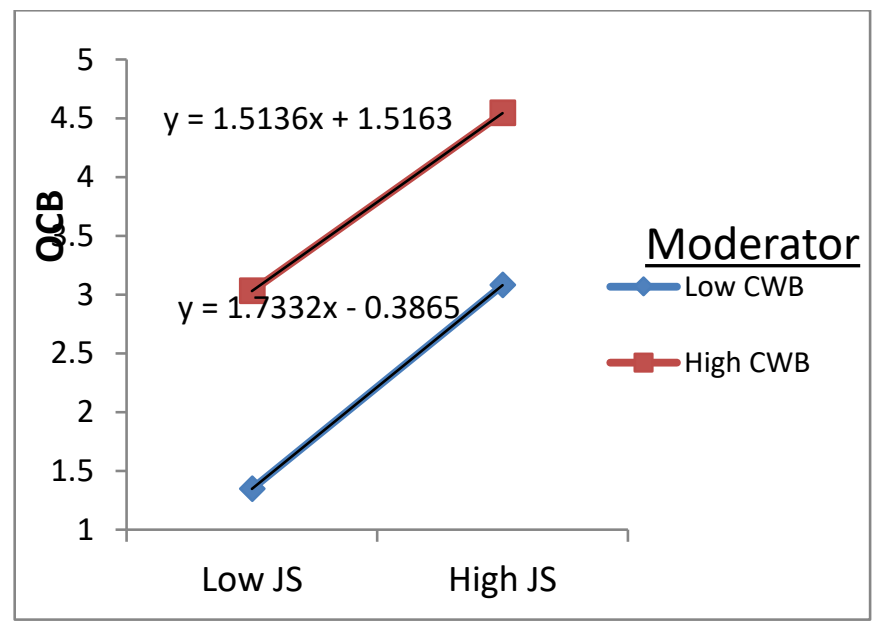

From the diagram above we are able to conclude that counterproductive work behaviour dampens the positive relationship between Job Satisfaction and Organizational Citizenship Behaviour. CWB is prejudicious to the organization or to co-workers. Several authors show a negative relationship between this behavior and work satisfaction, surmising that the shortage thereof - and therefore the succeeding want to 'get back' at the leader are the seeds of work deviance.

The Organizations ought to enhance the spontaneous organizational citizenship behaviors of workers to extend satisfaction and, hence, to extend the competitiveness within the organization. The survey results disclosed that job satisfaction encompasses an important positive impact on organizational citizenship behavior which 
counterwork productive behaviour encompasses a important negative dampening impact on the link between job satisfaction and organizational citizenship behaviours. Therefore, organizations will improve the work satisfaction of their workers by rising perceived operating satisfaction, social satisfaction, and remunerative satisfaction, which might then improve the organizational citizenship behaviours and reduce the negative impact of counterwork productive behaviour.

\section{REFERENCES}

1. Ajzen, I. \& Fishbein, M. (1977). Attitude-behavior relations: a theoretical analysis and review of empirical reseach. Psychological Bulletin, 84 (5), 888-918.

2. Angle, H.L. \& Perry, J.L. (1981). An empirical assesment of organizational commitment and organizational effectiveness. Administrative Science Quarterly, 26, 2-14.

3. Allen, N. J. \& Meyer, J. P. (1990). The measurement and antecedents of affective, continuance, and normative commitment to the organization. Journal of Occupational Psychology, 63, 1-18.

4. Allen, T.D., Barnard, S., Rush, M. C., \& Russell, J.E.A. (2000). Ratings of organizational citizenship behavior: Does the source make a difference? Human Resource Management Review, 10(1), 97-114.

5. Baker, B.A. (2005). The Good, The Bad And The Ugly: The Mediating Role of Attributional Style In The Relationship Between Personality and Performance. North Carolina State University.

6. Baron, R.M. \& Kenny, D.A. (1986). The moderator-mediator variable distinction in social psychological research: Conceptual, strategic, and statistical considerations. Journal of Personality and Social Psychology, 51, 1173-1182.

7. Bateman, T.S. \& Organ, D.W. (1983). Job satisfaction and the good soldier: The relationship between affect and employee "citizenship." Academy of Management Journal, 26, 587-595.

8. Borman, W.C., \& Motowidlo, S.J. (1993). Expanding the criterion domain to include elements of contextual performance. Personnel selection in organizations, 71-98.

9. Cohen, A. (2003). Multiple commitments in the workplace: An integrative approach. Mahwah, NJ: Erlbaum.

10. Cohen, A. \& Keren, D. (2008). Individual values and social exchange variables: Examining their relationship to and mutual effect on in-role performance and organizational citizenship behavior. Group and Organization Management, 33, 425-452.

11. Coleman, V.I. \& Borman, W.C. (2000). Investigating the underlying structure of the citizenship performance domain. Human Resource Management Review, 10, 25-44.

12. Dalal, S. R. (2005). A Meta-Analysis of the Relationship Between Organizational Citizenship Behavior And Counterproductive Work Behavior. Journal of Applied Psychology, Vol. 90, No. 6, 1241-1255

13. Deborah L.K \& McLean Parks J. (2001). The Good Soldier: Who is s(he)? Journal of Organizational Behavior. 22 (8), 939-959.

14. Deshpande, Et Al. (2005). The Impact of Emotional Intelligence on Counterproductive Behavior In China. Management Research News, Vol. 28, No. 5.

15. Gautam, T., Van Dick, R., \& Wagner, U. (2001). Organizational commitment in Nepalese settings. Asian Journal of Social Psychology, 4, 239-248.

16. Gautam, T., Van Dick, R., Wagner, U., Upadhyay, N. \& Davis, A. J. (2005). Organizational citizenship behavior and organizational commitment in Nepal. Asian Journal of Social Psychology 8, 305-314.

17. Gautam, Et Al. (2005). Organizational Citizenship Behavior and Organizational Commitment in Nepal. Asian Journal of Social Psychology, 8: 305-314.

18. Hoffman, B. J., Blair, C. A., Meriac, J. P., \& Woehr, D. J. (2007). Expanding the criterion domain? A quantitative review of ocb literature. Journal of Applied Psychology, 92(2), 555-566.

19. Jegadeesan, G. (2007). Job satisfaction: A conceptual framework. ICFAI Journal of Organizational Behavior, 6(4), 53-60.

20. James, L.R., \& Jones, A.P. (1980). Perceived job change and job satisfaction: An examination of reciprocal causation. Personnel Psychology, 33, 97-135.

21. Jaros, S.J, Jermier, J.M, Koehler, J.W., \& Sincich, T. (1993). Effects of continuance, affective, and moral commitment on the withdrawal process: An evaluation of eight structural equation models. Academy of Management Journal, 36(5), 951-995.

22. Kanter, R.M. (1968). Commitment and social organization: A study of commitment mechanisms in utopian communities. American Sociological Review, 33(4), 499-517.

23. Karambayya, R. (1990). Contextual predictors of organizational citizenship behavior. In L. R., Jauch \& J. L. Wall (Eds.), Best papers proceedings 1990, Academy of Management, San Francisco. 
24. MacKenzie, S. B., Podsakoff, P.M., \& Ahearne, M. (1998). Some possible antecedents and consequences of in-role and extra-role salesperson performance. Journal of Marketing, 62, 87-98.

25. Moorman, R.H. \& Blakely,G.L. (1995). Individualism - collectivism as an individual difference predictor of organizational citizenship behavior. Journal of Organizational Behavior, 6 (2), 127-142.

26. Neuman, G. \& Kickul, J. (1998). Organizational citizenship behaviors: Achievement orientation and personality. Journal of Business and Psychology, 13(2), 263-279.

27. Organ, D.W. (1997). Organizational citizenship behavior: It's construct clean-up time. Human Performance, 10(2), 85-97.

28. Podsakoff, P. \& MacKenzie, S.B. (1994). Organizational citizenship behavior and sales unit effectiveness. Journal of Marketing Research, 31, 351-363.

29. Podsakoff, P. \& MacKenzie, S.B. (1995). An examination of substitutes for leadership within levels of analysis framework. Leadership Quarterly, 6, 289-328.

30. Snape, E., Chan, A.W., \& Redman, T. (2006). Multiple commitments in the Chinese context: Testing compatibility, cultural, and moderating hypotheses. Journal of Vocational Behavior, 69, 302-314.

31. Somers, M.J. \& Birnbaum, D. (1998). Work-related commitment and job performance: It's also the nature of the performance that counts. Journal of Organizational Behavior, 19, 621-34.

32. Song, L.J., Tsui, A.S., \& Law, K.S. (2009). Unpacking employee responses to organizational exchange mechanisms: The role of social and economic exchange perceptions. Journal of Management, 35, 56-93.

33. Tang, T.L. \& A.H.S. Ibrahim, A.H.S. (1998), Antecedents of organizational citizenship behavior revisited: Public personnel in the United States and the Middle East. Public Personnel Management, 27(4), 529-551.

34. Yao, X. \& Wang, L. (2008). Socially oriented values and reciprocity norm predict organizational commitment. Asian Journal of Social Psychology, 11, 247-252. 